\title{
HARMONIZATION OF REGULATION BASED on Pancasila Values Through THE CONSTITUTIONAL COURT OF INDONESIA
}

\author{
Tedi Sudrajat* \\ Faculty of Law, Jenderal Soedirman University \\ E-mail: tedi.sudrajat@unsoed.ac.id
}

\begin{abstract}
The legal system which is adopted and applied in Indonesia was based on the formation from the founding fathers which is adjusted to the condition and the spirit of Indonesia as a nation known for its legal system as Pancasila. Ideally, Pancasila serves as the philosophy for the nation of Indonesia, as state's ideology and as the basis of the state. However, in reality, vertical conflicts (government and society) and horizontal conflict (inter-society) have created a variety of concerns, in which the sense of nationalism and diversity has diminished. The trigger is because Pancasila can only be understood as the ideology and the basis of the state, without saturating the meaning contained therein. The paradigm development of Pancasila based on legal state should demand the development of a democratic constitutional state, which juxtaposes the principles of a rule-of-law (nomocracy) with harmonious and complementary principles of the sovereignty of the people (democracy). This role can be solved by the Constitutional Court to harmonize the ideology of Pancasila in the Indonesia legal substance. When the legal development is integrated into meaning, the legal development which characterized by Pancasila can be realized to resolve the variety of community conflicts.
\end{abstract}

Keywords: Constitutional Court, Ideology of Pancasila, Legal Development, Legal Harmonization.

\footnotetext{
* A faculty member of Faculty of Law, Jenderal Soedirman University.
} 


\section{INTRODUCTION}

The independence of Indonesia which was declared on $17^{\text {th }}$ August 1945 has created a new entry for Indonesian towards the goal of independence; thus, Soekarno as the President stated that independence is not the goal, but it is a tool or a bridge in achieving the purpose of the nation. In building the state's foundation, Soekarno proposed National Principles which contains five National Principles called as Pancasila. It comprises two old Javanese words originally derived from Sanskrit: "pañca" (five) and "silla" ("principles"). Therefore, it is composed of five principles and contends that they are inseparable and interrelated:

1. Belief in One and Only God (Ketuhanan Yang Maha Esa),

2. Just and civilized humanity (Kemanusiaan Yang Adil dan Beradab),

3. The unity of Indonesia (Persatuan Indonesia),

4. A democratic life guided by wisdom in deliberation/representation (Kerakyatan Yang Dipimpin oleh Hikmat Kebijaksanaan, Dalam Permusyawaratan Perwakilan), and

5. Social justice for all the people of Indonesia (Keadilan Sosial bagi seluruh Rakyat Indonesia).

Practically, Pancasila can be simplified to three points named Tri Sila, which are: Nationalism, Democracy, and Divinity. By then, it is being simplified to Eka Sila, which are mutual assistance as the value of Indonesia for Indonesia. ${ }^{1}$ In this chain, the formulation and determination of National Principles are directed to accommodate the heterogeneous that encompass tribe, race, religion, tradition and ethnic complexity in the frame of pluralism through state symbol which is Bhineka Tunggal Ika (unity in diversity, diversity in unity). ${ }^{2}$

The Pancasila, as an ideology and National Principles of Indonesia which is the result of contemplation from the founding fathers of Indonesia, is the National Principles of Indonesia which is suitable for Indonesian. Pancasila is

\footnotetext{
Backy Krisnayuda, Pancasila \& Undang Undang (Relasi dan Transformasi Keduanya Dalam Sistem Ketatanegaraan Indonesia) [Pancasila \& Constitutions (Relation and Transformation in Indonesia Constitutional System)] (Jakarta: Prenadamedia Group, 2016), vi.

Yudi Latif, Negara Paripurna Pancasila [A State of Pancasila] (Jakarta: Gramedia, 2011), 369.
} 
the personality of the nation, and its values should be upheld by all Indonesian. However, the ideal condition is not always inline with the reality since there is a dynamic of legal issues, social and politics that created a horizontal and vertical conflict. It cannot be denied that the sense of nationalism has begun to wear off and become eroded by various factors that affect individual and group interests.

In the relation between law and politics, it is clear that the legal development, from the old order (orde lama) until the new order (orde baru), tends to have small progress and it is only for power interest. The subordinate of law under the control of the government, leads the corruption and authoritarian. ${ }^{3}$ Legal conditions and law enforcement that happened in Reformation era were almost the same, as declared by Syamsul Bachrie. He said that the old way of development which has embedded in legal development that is still being adopted to legitimate the power or group interest and has been contagious to politics development, social and economic approach until now. ${ }^{4}$

So far, legal development ${ }^{5}$ in Indonesia tends to move to artificial space with no directions. Along this way, the legal development in Indonesia tends to move to artificial space and no directions. The legal development after the Reformation era was always done with reactive, partial, and patchy ways. There is no fixed fundamental orientation of legal development that is becoming guidance that makes Indonesia legal development orientation and effective as tools to engineer and empower Indonesia that can lead to a fundamental purpose of the state which is the welfare of society (bonnum publicum) which is the ultimate goal of the State is to obtain the highest good for man and not merely good. That means the State should always seek and ensure the maximum

3 Dayanto, "Rekonstruksi Paradigma Pembangunan Negara Hukum Indonesia Berbasis Pancasila [Reconstruction of the Development of Law Paradigm of Indonesia based on Pancasila]", Jurnal Dinamika Hukum 13, no. 3 (2017): 498-509, https://doi.org/ 10.20884/1.jdh.2013.13·3.253.

Dayanto, "Reconstruction," 498-509

5 Dhaniswara K, Harjono, "Konsep Pembangunan Hukum dan Perannya Terhadap Sistem Ekonomi Pasar [The Concept of Development of Law and Its Role toward the Market Economy System]," Jurnal Hukum Ius Quia lustum 18, no. 4 (2011): 564-584 10.20885/iustum.vol18.iss4.art5 and Fence M. Wantu, "Mewujudkan Kepastian Hukum, Keadilan, dan Kemanfaatan Dalam Putusan Hakim di Peradilan Perdata [Realising Legal Certainty, Justice and Beneifts of Justice's Decosopm in Civil Courts]." Jurnal Dinamika Hukum 12, no. 3 (2012): 479-489, https:// doi.org/10.20884/1.jdh.2012.12.3.121. 
good for the citizens both on the level of quality and quantity. In the state, the citizens should be able to enjoy a safe and peaceful life, both spiritual and physical. Thus, the appropriate legal means are needed to be a bridge for the values of Pancasila in the legal development of Indonesia.

Associated with the socio-political issues, the latest case that potentially erodes the value of Pancasila is the threat of disintegration of the nation after the Election of Regional Head (Pemilihan Kepala Daerah or Pilkada) in Jakarta on $19^{\text {th }}$ April 2017. The elections of Jakarta's Regional Head in 2017 are assessed by many experts as a sign of change for social values that impact on potential loss of diversity essence. If this condition is still allowed, it will harm the sustainability of democracy, social and government system in Indonesia as well as the unity of Indonesia in the framework of Pancasila.

In line with those conditions, the researcher synchronized the claim from Try Soetrisno stated it is very painful when Pancasila became a Scapegoat for all problems and the unsuccessfulness of managing the life of a nation and the state. Pancasila was eventually blamed and accused of being the cause of the country's decline following the 1997 monetary crisis. Therefore, the political elite along with leading figures and leaders of this country are rushed to agree: $\mathrm{P}-4$ must be dismissed, BP-7 must be dissolved, some even argue that Pancasila is no longer needed to be taught in educational institutions from elementary to university level. There are at least three mistakes made by the nation. The first mistake is, this nation does not understand and comprehend the essence and meaning of Pancasila, and how to implement Pancasila in real life. The second mistake is the existence of some leading figures and leaders of this nation who make Pancasila just as a tool for their interests. Meanwhile, the third mistake is the lack of ability and willingness of people of this nation to make Pancasila as the foundation, orientation, and the signs of social life as a nation and state in all its aspects, covering various dimensions and all real life practices. The nation is not doing introspection and self-correction on the attitude and actions that have not been by Pancasila, but immediately get rid of Pancasila and all things about Pancasila. As the result of non-appreciative 
attitude and scapegoating of Pancasila, the state does not have a clear path, without clear direction, and without clear signs in facing globalization. ${ }^{6}$

Towards various problems, Joko Widodo as the President has taken a position to safeguard the value of Pancasila through the a speech in the anniversary of Pancasila in $2017^{7}$ which confirms that:

We need to learn from the bad experiences of other countries that are haunted by radicalism, social conflict, terrorism, and civil war. With Pancasila and the 1945 Constitution in the frame of Republic of Indonesia and Bhinneka Tunggal Ika, we can avoid the problem. We can live together and work together to promote the country. With Pancasila, Indonesia is the hope and referral of the international community to build a world that is peaceful, just and prosperous amid plurality.

Therefore, I invite the active role of ulama, ustadz, pastor, priest, monk, pedanda, public figure, educator, artist and culture, media player, bureaucracy, The Indonesian National Armed Forces (TNI) and Indonesian National Police (Polri) and all society component to maintain Pancasila. Understanding and practice Pancasila in the society, nation, and state must be continuously improved. Religious lectures, educational materials, the focus of news and debates on social media should be part of the deepening and practice of Pancasila values.

The government's commitment to strengthen Pancasila is clear and very strong. We continue to do various efforts. It has been enacted in Presidential Regulation Number 54 of 2017 on Working Unit President of the Development Ideology in Pancasila. Together with all components of the nation, this new institution is tasked to strengthen the practice of Pancasila in everyday life, which is integrated with development programs. Poverty alleviation, welfare distribution, and other programs become an integral part of the practice of Pancasila values.

There is no other choice unless we must work together to reach the ideals of the nation by Pancasila. There is no other choice, but the whole nation unites the heart, mind, and energy for unity and brotherhood. There is no other choice unless we have to return to our identity as a polite, soulless

\footnotetext{
Try Soetrisno, "Penyikapan terhadap Pancasila dan Efektifitasnya sebagai Landasan, Orientasi, dan Rambu-rambu bagi Kehidupan Berbangsa dan Bernegara di Masa Lalu, kini, dan Masa Mendatang [Addressing Pancasila and Its Effectiveness as Platforms Orientations, and Signs for Nations in the Past, Present, and Future]" delivered at Simposium dan Sarasehan Hari Lahir Pancasila, which took place at Gadjah Mada University on $14^{\text {th }}$ and $15^{\text {th }}$ August 2006 : 20-21.

Ahmad Romadoni, "Pidato Lengkap Jokowi di Upacara Hari Lahir Pancasila [A Complete Speech of Jokowi in the Commemoration of the Anniversary of Pancasila]," Liputan 6, June 1, 2017, http://news.liputan6.com/ read/2973374/pidato-lengkap-jokowi-di-upacara-hari-lahir-Pancasila.
} 
and tolerant nation. There is no choice but to make Indonesia a just, prosperous and dignified nation in the eyes of the international community. However, we must also be wary of all forms of understanding and movement that are not in line with Pancasila. The government must act firmly to the people that are against Pancasila, the 1945 Constitution of the Republic of Indonesia. The government must act decisively if there are still understandings and communism movements that have clearly been banned in Indonesia.

Again, keep the peace, keep the unity, and keep the brotherhood among us. Let us be polite, respectful, tolerant, and mutually helpful for the benefit of the nation. Let's work hand in hand, work together for the sake of Indonesia's development.

We are Indonesia, We are Pancasila. All of you are Indonesian, all of you are Pancasila. I am Indonesian, I am Pancasila.

From the explanation above, the questions appeared are the function and the role of Pancasila in the life of the nation that are missed interpreted, and sometimes are misused for certain needs, and no longer achieve a fundamental goal for life in nation and state. Pancasila is not in empty space. However it lives in the history and the mind of Indonesian, that is being an object that rose pro and cons, but there is also dialectic process from the various perspective about Pancasila.

This paper will review a problem about the ideology of Pancasila position in the structure of Legislation, the means of Pancasila in Legislation in search of the relevancy of Pancasila values in the life of the nation and the role of Constitutional Court of Indonesia to harmonize the regulation based on Pancasila Values. All the points will lead to the answer of Ideology of Pancasila in recent concept, whether it is still relevant or should be changed.

\section{METHOD}

This paper used a doctrinal approach. This approach focused on legal synchronization either vertically or horizontally. To analyze the problems, the author used a statute approach, analytical approach and conceptual approach by emphasizing on the syllogistic process of thinking. For the analytical 
method, the authors used content analysis through grammatical and systematic interpretation. The result will be harmonized with norms, theories and doctrines through the use of multiple interpretation models, both grammatically and systematically.

\section{DISCUSSION}

\subsection{The Position of Pancasila Ideology in the Structure of Legislation}

From the time the proclamation of independence was declared in August 17, 1945, the journey of constitutional life of the Republic of Indonesia as a sovereign state is considered relatively "young" i.e., 73 years, compared to 242 years of the United States of America, whose independence was declared on July $4^{\text {th }}, 1776$. Nevertheless, admittedly the idea and or concept of constitutional implementation has always accompanied the state administration, regardless implementation empirical level of this idea often experienced the ups and downs, it is therefore interesting to analyze the notion, as the turn of the era in a nation's history has often encompassed a completely different characteristic.

Awareness of the state's constitutionalism founders has grown and developed in line with the founder of the nation's activities to fight and prepare for the independence of Indonesia. This is documented in the series of the history of formation and discussion of Constitution as stated in meeting minutes of the Hansard of the Investigating Committee for Preparatory Work for Independence (Badan Penyelidik Usaha-Usaha Persiapan Kemerdekaan Indonesia or BPUPKI) and the Preparation Committee for Indonesian Independence (Panitia Persiapan Kemerdekaan Indonesia or PPKI) which may then be ratified on August 18, 1945. One of the main discussion was creating the ideology of Indonesia.

In general, ideology is a set of action-oriented ideas or thoughts that organized into a regular system. In ideology, it contains three elements, namely (1) the existence of an interpretation or understanding of reality; (2) accommodate a set of moral values or prescriptions; (3) held orientation of an 
action, ideology is a guideline of activities to realize the values contained in it. Substantively, Pancasila is an ideology created by the people of Indonesia. It means, ideology declared a goal to be achieved as a point of pressure and included the values as the basic guidelines for the state and its life.

Pancasila as the ideology of the state has aimed that every field of government or any related to the life of the state must be based on the point of its implementation, limited in the motion of its implementation, and directed in achieving its goals with Pancasila. By declaring this aspiration to be achieved it is essentially the fifth principle, wishing to bring out social justice for all the people, who are imbued with another principle as unity. ${ }^{8}$

In its historical development, Ideology of Pancasila was set as a fundamental norm of the state. Notonagoro was the first to place Pancasila as a staatsfundamentalnorm. ${ }^{9}$ Speech Anniversary Notonagoro in Airlangga University on 10 November 1955 suggests that Pancasila is a fundamental norm of the state or according to the principal use of the term fundamental principle of the state. ${ }^{10}$ The origin of the term staatsfundamentalnorm first introduced by Hans Nawiasky in his book Allgemeine Rechtslehre System als der rechtlichen Grundbegriffe published in 1940. According to Nawiasky, in a state which is a unity of the legal system, there is a norm which is the highest (der Oberste Norm), which has a higher position of the constitution (die verfassung). Based on this supreme norm, the constitution of a state is formed. Nawiasky says that the highest norms in the unity of the state legal system is called Grundnorm." However, both of the opinions above have the difference. Grundnorm, as stated by Hans Kelsen, is the highest norm and basically unchanged. But Hans Nawiasky see that the highest norms in a state always has the possibility of changing, either by events

Bakry, Pancasila: Yuridis Kenegaraan [Pancasila: Judicial State] (Yogyakarta: Liberty, 1997), 67.

Jimly Assihiddiqie, Pengantar Ilmu Tata Negara [Introduction to Constitutiona Law] (Jakarta: Secretary General and Secretariat of The Constitutional Court of Republic of Indonesia, 2006), 43.

10 Notonagoro, Dies Natalis Speech, "Pancasila sebagai Ideologi dalam berbagai bidang kehidupan bermasyarakat, berbangsa, dan bernegara [Pancasila as Ideology in Various Fields in Society]" (Speech at Airlangga University in November $10^{\text {th }}$ 1995).

11 Kaelan, Inkonsistensi Dan Inkoherensi Dalam Undang-Undang Dasar Negara Republik Indonesia Tahun 1945 Hasil Amandemen [Inconsistency and Incoherence in the 1945 Constitution of the Republic of Indoensia from the Amendment] (Jakarta: Badan Pengkajian Majelis Permusyawaratan Rakyat Republik Indonesia, 2017), 38. 
such as rebellion, coup d'etat, putsch, or anschluss. Pancasila is seen as a legal ideal (rechtsidee) which is the guide star. This position requires the formation of a positive law to achieve ideas in Pancasila, and can be used to test positive law.

It can be concluded from the political aspect that Pancasila can be viewed as a modus vivendi or a sublime agreement that unites all primordial ties into one nation and the whole of Indonesia which is vast and complex in principle of unity. Pancasila which was supposed to be a "middle path" neither liberal nor socialist, that charted a new course for philosophy and politics. ${ }^{12}$ Nevertheless, Pancasila, as stated by Notonagoro, is not a political compensation, but the result of the profound meditations of the soul, the result of an orderly and thorough investigation of inventory on a broad base of knowledge and experience which was not reached easily by every human being. ${ }^{13}$

Based on philosophical perspective, Pancasila is the fundamental believe of a society aspired by the people and served as the fundamental of national enforcement obtained from the values of life of Indonesian anchestors. Meanwhile, according to the legal perspective, Pancasila is the legal ideal (rechtside) which should be the legal basis and purpose of every law in Indonesia. Therefore, every law formulated in Indonesia should be based on Pancasila and it can conclude all contents consistency from any hierarchy level. It can be concluded that Pancasila is an instrument to unite the heterogeneity of Indonesian people which consists of many races, religions, cultures and languages. In addition, it is also an awareness for the whole elements of Indonesian people from Sabang to Merauke by ignoring the differences and partitions so that they can unite in the Unitary State of Republic Indonesia.

\footnotetext{
12 Pranoto Iskandar, "The Pancasila Delusion," Journal of Contemporary Asia 45, no. 3 (2016). 723-735, https://doi. org/10.1080/00472336.2016.1195430

13 Soekarno, Filsafat Pancasila Menurut Bung Karno [The Philosophy of Pancasila based on Bung Karno] (Yogyakarta:Media Presindo, 2006), 2.
} 
Pancasila is filosofischegrondslag and common platform or kalimatunsawa. ${ }^{14}$ According to Bernard Arief Sidharta, legal ideal (rechtidee) is a regulation to rule the society behavior based on the ideas, feels, intentions, thoughts of the society. It is related to the law meaning perceptions which consist of three elements such as justice, benefit (doelmatigheid) and legal certainty. The legal idea is created in human thought and soul as the combination of the views of life, religious believe, and social reality appeared in the society behavior regulation process which realizes those three elements. The legal idea in the dynamics of social life will give impact as the building principle, critical norms, and motivational factors in the law enforcement (the legal formulation, finding and stipulation) and behaviour. In addition, the legal idea will simplify its description in many regulations, rules, behaviours, and keep the law enforcement in consistency. So, the rule of law should be a reflection of legal ideas inside any legal principle arranged in a system. ${ }^{15}$

According the explanation above, the spirit and the soul of every law/ norm/regulation in Indonesia must be the implementation of the spirit and soul of Pancasila. Thus, both the national and regional governments have power to create and formulate law in form of regulation, government regulation, president regulation, regional regulation and governor/regent/ mayor regulation that should set Pancasila as the legal idea and every regulations should not against the moral principles of Pancasila.

Therefore, the national legal development guided by Pancasila will be appropriate with:

a. The first principle which is the acknowledgment to be a country believing in the one and only God instructs to all legal products to ensoul the religious principles.

${ }_{14}$ Jimly Asshiddiqie, Ideologi, Pancasila dan Konstitusi [Ideology, Pancasila, and Constitution] (Jakarta: Constitutional Court of Republic of Indonesia, 2009), 10.

15 Bernard Arief Sidharta, Refleksi tentang Struktur Ilmu Hukum: Sebuah Penelitian tentang Fundasi Kefilsafatan dan Sifat Keilmuan Ilmu Hukum sebagai Landasan Pengembangan Ilmu Hukum Nasional [Reflection of the Structure of Law: A Research on Philosophical Foundation and the Nature of Law as the Basic for Development of National Law] (Bandung: Mandar Maju, 1999), 181. 
b. The second principle is every law should in line with humanity which means the law formulated cannot ignore the humanities and against human rights.

c. The third principle is the legal development should be unity, which means keeping the pluralities and the unity in diversity.

d. The fourth principle is the law has to be democratic; and

e. The fifth principle is the law should bring the social justice and prosperity.

Thus, the national legal development policy and its aspects must be rational and uphold the spiritual values, ethics and moral. It has to be created based on the honor principle upon human prestige and dignity by guaranteeing the human rights protection, protecting the whole Indonesian people and homeland, and serving the national interests. In addition, it has to be built upon the democracy principle which means people have a big room to contribute in every law formation and renewal to arrange and formulate the new law either by direct or indirect participation. Furthermore, the national law must be fair on the social justice so the equity can be reached.

The direction of national law is integrated with the direction of development in another field which needs adjustment. Even if the legal development starts from the ideas based on the 1945 Constitution of the Republic of Indonesia, adjustment is needed with the level of society growth that wishes to be realized in the future. According to common term used in Indonesia, the legal development is not identic with legal or regulation formulation. Legal formulating as many as possible does not mean creating the law. Legal state is not law state. Legal formulating only means creating legal norms. In fact, social order, economy, culture and politics are not solely a normative order. Thus, there should be certain spirit needed so that they can have capacity. ${ }^{16}$

16 Dhea Yudhista, "Arah Pembangunan Hukum Nasional Menurut UUD NRI 1945 [The Development of National Law based on the 1945 Constitution]," February 29, 2016, https://fh.umj.ac.id/arahpembangunan-hukum-nasionalmenurut-undang-undang-dasar-negara-republik-indonesia-tahun-1945/. 
The consequence for the legal product which is not in line with the spirit and soul of Pancasila, based on hierarchy principle, is that it does not have legal power since there are three consequences for following the hierarchy principle. They are:

a. A lower regulation cannot exist against the higher regulation;

b. A lower regulation can only be alienated by the authority of the regulation with the same level or having the higer level;

c. If the material of the lower regulation is not in line with the higher regulation; therefore, it cannot be imposed.

Pancasila, which is the source of any national legal source in the Indonesian legal system which gives direction and soul, becomes the norms paradigm in substance of 1945 Constitution. The interpretation of legal norms in 1945 Constitution as the highest law will be based on the national core in Pancasila with the function as the legal idea which is going to be the basic and source of life vision or the life philosophy of the nation that is the guide in formulating law and other lower regulation. The legal idea, life philosophy and nation morality which are the source of any state legal source will be the standard to value of legal policy. Otherwise, it can be used as the fundamental paradigm for policy making in law and regulation field or social, economic and political field. ${ }^{17}$

\subsection{Judicial Review as Legal Harmonization Tool based on the Value of Pancasila}

The authority of judicial review is an examining right which belongs to the judiciary toward the regulation related to the matter whether it is in line or against the regulation with the higher level. In the United States, the authority of judicial review is considered as a natural authority of judiciary, even before it was adopted in the constitution of the United States. It is because the Constitution of United States, at the beginning, does not explicitly regulate the authority of judicial review of federal court. ${ }^{18}$ Judicial

${ }_{17}$ Maruarar Siahaan, Undang-undang Dasar 1945 Konstitusi yang Hidup [A Living 1945 Constitution] (Jakarta: Secretary General and Secretariat of the Constitutional Court of the Republic of Indonesia, 2008), 59.

18 William Michael Treanor, "Judicial Review Before Marbury," Stanford Law Review 58, no. 2 (2005): 455-562. 
review refers to the authority of a court to review the constitutionality of legislative and executive actions. It means that a court can invalidate laws or decisions contrary to higher laws or regulations, particularly the Constitution. The term of judicial review is often used interchangeably with constitutional review. ${ }^{19}$

Through the authority of judicial review, the judiciary can contribute to preventing the misuse of power by using the regulation formulated by the government. ${ }^{20}$ In some states, the authority of judicial review is conducted by the constitutional court. This kind of court can be found in Germany, Italia, Austria, Spain and Belgium. Based on the authority gained in revoking legal product formed by the legislatives, Hans Kelsen described the authority of constitutional court as negative legislators. ${ }^{21}$ Even so, he distinguished how the parliament and constitutional court make law. The parlements, as the positive legislators, create law directly using their authority while constitutional court, as negative legislators, make law using the revocation. ${ }^{22}$

Discussing the position of Pancasila, the Constitutional Court stated that, according to Article II Additional Rule of the 1945 Constitution of the Republic of Indonesia, "in line with the stipulation of Amendment of this Constitution, the 1945 Constitution of the Republic of Indonesia consists of the preamble and articles". Meanwhile, the preamble of The 1945 Constitution of Republic of Indonesia, especially the fourth paragraph, substantively contains Pancasila as the national principle, therefore, the amendment of the 1945 Constitution of the Republic of Indonesia only affects to the articles not to the preamble. In this regard, Pancasila is inseparable to the preamble of the the 1945 Constitution of the Republic of Indonesia which automatically there is no chance to change Pancasila as the national principle. ${ }^{23}$

19 Pan Mohamad Faiz, "Legal Problems of Dualism of Judicial Review System in Indonesia". Jurnal Dinamika Hukum. 16, no. 1 (2016): 87-195. https://doi.org/10.20884/1.jdh.2016.16.2.535.

20 David S. Law, "A Theory of Judicial Power and Judicial Review," Georgetown Law Journal. 97. (2009): 723.

${ }_{21}$ J. Uzman, T. Barkhuysen and M.L. van Emmerik, "The Dutch Supreme Court: A Reluctant Positive Legislator?" Electronic Journal of Comparative Law 14, no.3 (2010): 1-35.

22 Alec Stone Sweet, "The Politics of Constitutional Review in France and Europe." International Journal of Constitutional Law 5, no. 1 (2007): 69-92.

23 "MK Tegaskan Kedudukan Pancasila dalam UUD 1945 [The Constitutional Court Affirmed the Position of Pancasila in the Constitution]." Constitutional Court of Republic of Indonesia, accesed August 1, 2017, http://www. mahkamahkonstitusi.go.id/index.php?page=web.Berita\&id= 13296\&menu=2\#.WU n8P5KGPIU. 
By the stipulation of Pancasila as staatsfundamentalnorm, the formulation, the application and the enforcement of law cannot be separated from the values of Pancasila. The problem is, by setting Pancasila as staatsfundamentalnorm means that Pancasila has the higher status than the the 1945 Constitution of the Republic of Indonesia. Thus, Pancasila is not considered as the meaning of constitution since it has higher position. This discussion can be conducted by looking back at basic norms and constitution concept according to Kelsen and the development by Hans Nawiasky, as well as the relation between Pancasila and the 1945 Constitution of the Republic of Indonesia. Until now, there is still polemic among law experts about which one is the source of any legal source, which can be Pancasila, the Preamble of the 1945 Constitution of Republic of the Indonesia or the proclamation of independence.

Since Pancasila is the highest norm in legal structure and its position is higher than the Constitution, Pancasila becomes the requirement for the application of the 1945 Constitution of the Republic of Indonesia. In other words, Pancasila has existed before the emergence of the 1945 Constitution of the Republic of Indonesia. Therefore, it places Pancasila as a tool to examine either constitution or legislation.

For that reason, the Constitutional Court should be able to use Pancasila as a testing tool in judicial review in the Constitutional Court. It is pivotal because almost all law examinations only use the 1945 Constitution of the Republic of Indonesia as the testing tool whereas Pancasila is the value that animates the 1945 Constitution of the Republic of Indonesia. By affirming Pancasila as the testing tool in judicial review in the Constitutional Court, it opens the way to internalize Pancasila concretely in the realm of legislation. Through this way, all laws that contradict with Pancasila can be repealed through judicial review mechanism. It is expected that there is no law either formally or materially that contradicts with Pancasila. Furthermore, this matter will implicate to the legislation process in parliament where the circumspection in regulating law in a good way and content that do 
not contradict with Pancasila is more and more increasing. In the same time, the internalization process of Pancasila in every law will be more and more developed. Hence, Pancasila does not only become rhetorical-semantic sentences which are too high-sounding, but it can also incarnate in the life of nation and state as the basic principle and the guidance.

\subsection{The Relevance of Pancasila in the Life of Nation in Indonesia}

As the philosophy of life, the value of Pancasila is ideal as foundation of nation and state in Indonesia. The basic idea about the identity of nation and its role in giving the identity of state system and legal system was stated by Carl von Savigny (1779-1861) with his volkgeist theory that can be equalized with the heart of nation and national identity. Moreover, in France, there is raison d' etat theory or reason of state theory which determines the existence of a nation and state (the rise of sovereign, independent and national state).

Constitutionally, commitment of having nation and state of Indonesia has been firmly declared in the fourth paragraph of the Preamble of the 1945 Constitution of the Republic of Indonesia. That commitment is a crystallization of nationality spirit that historically cristalizes in the form of National Resurgence 1908 movement, Youth Pledge on October $28^{\text {th }}, 1928$ and Declaration of Indonesian Independence on August $17^{\text {th }}, 1945$ as the peak. All components of nation are restless because of the nowadays condition of nation and the prospect of nation in the future. Various discussions, seminars, workshops, symposiums, and others that are often conducted now in all regions of Indonesia are the strong indicators signifying that all components of nation have very strong nationality commitment. However, national policy which is comprehensive, coherent, and sustainable through integrated comprehension in the value of Pancasila is needed.

Pancasila as a foundation of the state, the ideology of the nation and the philosophy and the way of life of the nation are contains the basic values, instrumental values and values of praxis. In addition, Pancasila as 
an open ideology has at least two dimensions of values, namely ideal values and actual values. However, these values are influenced by the values which brought by globalization, resulting in a shift in tapping, which also leads to changes in meaning and positioning of Pancasila. Concretely, Pancasila is adopted by the state or the government and the people of Indonesia as a whole, not as a tool or monopoly of a person or any particular group. It explained that Pancasila as a national Ideology is also a source of value for Indonesian law and create legal ideals for the people of Indonesia as a whole. Pancasila became the reference of political and state life in Indonesia.

In the life of the Indonesian nation, Pancasila is a philosophy of life which developed in the socio-culture of Indonesia. The value of Pancasila is regarded as the basic value of the nation's culture. This value believed as the soul and personality of the nation and fundamentally give a character (personality, identity) for Indonesia. As a philosophy, Pancasila reflects the values and create essential aspect of the people of Indonesia such as:

1. Believe in God;

2. Human conscience;

3. Truth; and

4. Justice

3.3.1 The implementation of Pancasila as the National Philosophy System are:

\section{Sila 1 (First Principle) Belief in One and Only God}

Implementation of the first principle of Pancasila from the perspective of the philosophical system is that belief in God Almighty is not a dogma or belief which can not be verified by reason, but a belief that stems from human consciousness as God's creature. From the perspective as the foundation of the state, Belief in God becomes the main source of life values of the Indonesian nation, animating and underlying and guiding the other principles of the second principles until the fifth principle. This closeness is in accordance with the statement 
in the Preamble of the 1945 Constitution namely "The One Almighty God....". In national ideology this principles states that within the state of Indonesia there is no and there should be no ideology that negates or deny the existence of God Almighty (Atheism) and that there should be Belief in the Supreme (Monotheism) with tolerance to freedom to embrace religion in accordance with his confidence.

\subsubsection{Sila 2 (Second Principle) Just and Civilized Humanity}

In the aspect of the philosophical system of the second principles, it has the view that the Indonesian people claim human dignity as the creature of God Almighty. This means that man is equally recognized, equal to his fundamental rights and obligations, without distinction of race, heredity, religion, social standing and others. As the foundation of the state, this principle related with the values of Indonesia's human rights and obligations. Every citizen is guaranteed the right and freedom that governs the human relationship with God, with another person, with his society and the natural environment. In the paradigm of Pancasila as the ideology of the state, every Indonesian human being is part of the citizens of the world who believe in the principle of equality and dignity as a servant of God.

\subsubsection{Sila 3 (Third Principle) Unity of Indonesia}

The philosophy of Pancasila of the third principles contains the values of bureaucracy and ethical values which include the position and dignity of the Indonesian people to appreciate the balance between private and public interest. In the point of view, this principles emphasizes the importance of diversity in the fields of culture, religion, belief in God Almighty and ethnicity to raise awareness of "Single Unity". Pancasila as a national ideology is a manifestation of nationalism that provides a place for cultural and ethnic diversity. This principle will create togetherness and solidarity. 


\subsubsection{Sila 4 (Fourth Principle) Democratic Life Guided by Wisdom in Deliberation/Representation}

The position of Pancasila as a system of philosophy in the fourth principles reflects the attitude and outlook of life regarding the value of truth and the high validity to prioritize the interests of the state and society. Manifestation of the sovereignty of the people and the value of "representation"' related to deliberation within the framework of Indonesian democracy. The context in this national ideology contains the notion of popular sovereignty which reflects the value of togetherness, kinship and mutual cooperation.

\subsubsection{Sila 5 (Fifth Principle) Social Justice for All Indonesian People}

In the nation's philosophical system, the fifth principle includes that social justice means justice prevailing in society in all spheres of life, both material and spiritual. Pancasila contains the value of the necessity of collectively achieving equitable progress and social justice. The value of Pancasila as a national ideology includes the concept of social justice to provide assurance and achieve a decent and respectable standard of living in accordance with its nature, and place the value of democracy in the economic and social sphere.

Based on the essence of the five principle of Pancasila, the life of nation in Indonesia will always be related with the identity of the nation based on its characteristics. Mochtar Kusumaatmadja argues that all developing societies are always characterized by legal functions to ensure changes occurs in an orderly condition. ${ }^{24}$ Based on Mochtar's opinion, there are two important legal functions in the effort to carry out national development, Firstly, the legal basis, and Secondly, control over power. Those two legal function has relevancy with nation's character.

National Policy of Nation's Character Development indicates that the situation and the condition of nation's character that are apprehensive

24 Romli Atmasasmita. Teori Hukum Integratif [Theory of Integrated Law] (Yogyakarta: Genta Publishing, 2012$), 65$. 
lead the government to take the initiative in prioritizing the development of nation's character. The development of nation's character becomes the main stream of national development. It means that each development effort must be directed to give positive impact to the character development. Regarding that matter, constitutionally it has been reflected in the mission of national development that places character education as the first of eight missions in order to realize the vision of national development, as stated in Long-Term National Development Plan Year 2005 - 2025 (Law of the Republic of Indonesia Number 17 Year 2007), which is

“...actualizing nation's characters that are strong, competitive, noble, and having high moral standards based on Pancasila. Those characters are characterized by Indonesian society's character and behavior which are various, believing in One God, virtuous, tolerant, cooperative, patriotic, dynamic, and science and technology-oriented."

That policy is very wide, since substantively and operationally, it is related to "...development all potential aspects of nation which are multidimensional because they cover the dimensions of nationality which are still in progress." In this case, it is also mentioned that: ${ }^{25}$

(1) Character is a very essential thing in having nation and state, the lost of character will cause the lost of future generation of nation;

(2) Character has role as "rudder" and strength, so this nation is not oscillated;

(3) Character does not come by itself, but it must be developed and formed to be dignified nation. Furthermore, it is firmly declared that the development of nation's character must be focused on “... three big matters, which are:

a. to grow and strengthen the identity of nation,

b. to keep the integrity of the Republic of Indonesia, and (3) to create Indonesian society that is noble and dignified."

${ }_{25}$ Udin Saripudin Winataputra, "Implementasi Kebijakan Nasional Pembangunan Karakter Bangsa Melalui Pendidikan Karakter (Konsep, Kebijakan, dan Kerangka Programatik) [The Implementation of National Policy on the Development of the Character of the Nation through Character Education (Concept, Policy, and Pragmatic Framework)]" (Paper., 2010). 
The development of nation's character is not only enough in the essence of physical development, but also stronger orientation which is the basic foundation of nation's character development where it is needed. Therefore, physical essence of development starts from the internalization of values to lead to the value development or vice versa, the development that is oriented to physical matter animated by the spirit of increasing socio-community and cultural values. In this case, Indonesia has Pancasila as the foundation to develop the nation's character. Danielle N. Lussier and M. Steven Fish stated that, if Indonesian people believe that they can make a difference, they are more likely to take part in political actions to defend their right. ${ }^{26}$

To realize the application of Pancasila in overcoming nationality problems in Indonesia, the application of Pancasila can be done in education sector:

1. Sharing knowledge, basic knowledge, scientific knowledge, and philosophical knowledge regarding Pancasila. These things are pivotal for the leaders and the scientists;

2. Raising the awareness, through being aware and knowing the growth of ourselves will help someone to apply the values of Pancasila;

3. Improving the obedience like always being ready in fulfilling the obligations physically and mentally, physical thing comes from outside for instance government meanwhile mental comes from ourselves;

4. Developing strong ability, the booster to behave based on the high values of Pancasila;

5. Introspection, by always assessing ourselves whether we already behave well or bad in applying Pancasila. ${ }^{27}$

Pancasila is a guidance in national law politics; thus, national law must be lead to: (1) keeping the integrity of nation either ideological aspect or territorial aspect; (2) based on the effort of developing democracy and nomocracy at once; (3) based on the effort of developing social justice for

\footnotetext{
Danielle N. Lussier, and M. Steven Fish, "Indonesia: The Benefits of Civil Engagement," Journal of Democracy 23, no.1 (2012): 70-84, https://doi.org/10.1353/jod.2012.0017

27 Kaelan, Pancasila: Yuridis Kenegaraan [Pancasila: Judicial State] (Yogyakarta:Liberty, 1993), 178.
} 
all Indonesians; and based on the principle of religious tolerance which is civilized. Pancasila is the highest material source which determines content material in regulating law as well as philosophical parameter in examining constitutionality of legal norm. ${ }^{28}$ Moreover, if we want to be honest and pure in hearing our own conscience, it is not Pancasila that is wrong, but rather the human who applies Pancasila that is wrong.

\section{CONCLUSION}

1. Pancasila is a fundamental norm of the Republic of Indonesia which becomes source of legal source and it will be the standard in assessing legal policy or it can be used as the paradigm that becomes the foundation of policy making in the aspect of legislation, social, economic, and politic. It can also be stated that Pancasila is a unifying means for the heterogeneity of Indonesian nation which consists of various ethnic groups, religions, cultures and languages. Pancasila is also essentially a form of awareness of all elements of the nation, regardless to the differences and barriers among differences to unite within the Unitary State of the Republic of Indonesia.

2. Implementation of Pancasila in national legal development can be actualized by harmonizing Pancasila into regulation in a hierarchical manner. Therefore, the Constitutional Court is insisted to conduct judicial review toward the legal substance in order to make it consistent with the Pancasila ideology. The aims to harmonize the regulation based on Pancasila value is to create legal development in a hierarchical manner which correlates with the four goals of the state (1) to protect the entire nation and Indonesian homeland; (2) to improve the public welfare; (3) to educate the life of the nation; and (4) to participate in the implementation of world order based on independence, lasting peace, and social dignity. Normatively, Indonesian constitutional identity is incarnated in a consensus that maintains the upholding of Indonesian constitutionalism into the five basic principles of

${ }_{28}$ Backy Krisnayuda, "Pancasila \& Undang Undang [Pancasila \& Constitution],", 55 
Pancasila served as an ideological-philosophical foundation in achieving and realizing the four goals of the state;

3. The recent problems are only the testing tool toward the existence of Pancasila. Thus, every state's policy that is made by state organizers including the effort of conducting national development should be accordance with the ideology of Pancasila through the developing nation's character, which are:

a. Keeping the integration of nation and state, either ideologically or territorially.

b. Actualizing democracy and nomocracy at once and as one unity that is never separated.

c. Raising common prosperity and social justice for all Indonesians.

\section{BIBLIOGRAPHY}

Assihiddiqie, Jimly. Pengantar Ilmu Tata Negara [Introduction to Constitutiona Law]. Jakarta: Secretary General and Secretariat of The Constitutional Court of Republic of Indonesia, 2006.

. Ideologi, Pancasila dan Konstitusi [Ideology, Pancasila, and

Constitution]. Jakarta: Constitutional Court of the Republic of Indonesia, 2009.

Atmasasmita, Romli. Teori Hukum Integratif [Integrative Law Theory]. Yogyakarta:

Genta Publishing, 2012.

Bakry. Pancasila: Yuridis Kenegaraan [Pancasila: Judicial State]. Yogyakarta: Liberty, 1997.

Constitutional Court of Republic of Indonesia. "MK Tegaskan Kedudukan Pancasila dalam UUD 1945 [The Constitutional Court Affirmed the Position of Pancasila in The Constitution]." Accesed August 1, 2017. http://www. mahkamahkonstitusi.go.id/index.php?page=web.Berita\&id=13296\&menu=2\# . WU n8P5KGPIU.

Dayanto. "Rekonstruksi Paradigma Pembangunan Negara Hukum Indonesia Berbasis Pancasila [Reconstruction of the Development of Law Paradigm 
of Indonesia based on Pancasila]". Jurnal Dinamika Hukum 13, no. 3 (2017): 498-509. https://doi.org/10.20884/1.jdh.2013.13.3.253.

Faiz, Pan Mohamad. "Legal Problems of Dualism of Judicial Review System in Indonesia". Jurnal Dinamika Hukum. 16, no. 1 (2016): 87-195. https://doi. org/10.20884/ 1.jdh.2016.16.2.535.

Harjono, Dhaniswara K. "Konsep Pembangunan Hukum dan Perannya Terhadap Sistem Ekonomi Pasar [The Concept of Development of Law and Its Role toward the Market Economy System]." Jurnal Hukum Ius Quia Iustum 18, no. 4 (2011): 564-584 10.20885/iustum.vol18.iss4.art5.

Iskandar, Pranoto. “The Pancasila Delusion." Journal of Contemporary Asia 45, no. 3 (2016). 723-735, https://doi.org/10.1080/00472336.2016.1195430.

Kaelan. Pancasila Yuridis Kenegaraan.Yogyakarta: Liberty, 1993.

-------------. Inkonsistensi Dan Inkoherensi Dalam Undang-Undang Dasar Negara Republik Indonesia Tahun 1945 Hasil Amandemen [Inconsistency and Incoherence in the 1945 Constitution of the Republic of Indoensia from the Amendment]. Jakarta: Badan Pengkajian Majelis Permusyawaratan Rakyat Republik Indonesia, 2017.

Krisnayuda, Backy. Pancasila \& Undang Undang (Relasi dan Transformasi Keduanya Dalam Sistem Ketatanegaraan Indonesia) [Pancasila \& Constitutions (Relation and Transformation in Indonesia Constitutional System)]. Jakarta: Prenadamedia Group, 2016.

Law, David S. "A Theory of Judicial Power and Judicial Review." Georgetown Law Journal 97 (2009): 723.

Latif, Yudi. Negara Paripurna Pancasila [A State of Pancasila]. Jakarta: Gramedia, 2011.

Lussier, Danielle N and M. Steven Fish. "Indonesia: The Benefits of Civil Engagement." Journal of Democracy 23, no.1 (2012): 70-84, https://doi. org/10.1353/jod.2012.0017. 
Notonagoro. "Pancasila Sebagai Ideologi dalam Berbagai Bidang Kehidupan Bermasyarakat, Berbangsa, dan Bernegara [Pancasila as Ideology in Various Fields in Society]." Dies Natalis Speech at Airlangga University on November $10^{\text {th }} 1995$ in, Jakarta: BP-7 Pusat, 1991.

Romadoni, Ahmad. "Pidato Lengkap Jokowi di Upacara Hari Lahir Pancasila [A Complete Speech of Jokowi in the Commemoration of the Anniversary of Pancasila]." Liputan 6, Juni 1, 2017. http://news.liputan6.com/read/2973374/ pidato-lengkap-jokowi-di-upacara-hari-lahir-Pancasila.

Sidharta, Bernard Arief. Refleksi tentang Struktur Ilmu Hukum :Sebuah Penelitian tentang Fundasi Kefilsafatan dan Sifat Keilmuan Ilmu Hukum sebagai Landasan Pengembangan Ilmu Hukum Nasional [Reflection of The Structure of Law: A Research on Philosophical Foundation and The Nature of Law as the Basic for Development of National Law]. Bandung: Mandar Maju, 1999.

Siahaan, Maruarar. Undang-undang Dasar 1945 Konstitusi yang Hidup [A Living 1945 Constitution]. Jakarta: Secretary General and Secretariat of the Constitutional Court of the Republic of Indonesia, 2008.

Siswimihardjo, Koento Wibisono. Pancasila Suatu Telaah Ideologik Dalam Perspektif 25 Tahun Mendatang [Pancasila, An Ideological Analysis for the Next 25 Years Perspective]. Yogyakarta: Pusat Studi Pancasila Universitas Gadjah Mada, 1999.

Soekarno. Filsafat Pancasila Menurut Bung Karno [The Philosophy of Pancasila based on Bung Karno]. Yogyakarta: Media Presindo, 2006.

Soetrisno, Try. "Penyikapan terhadap Pancasila dan Efektifitasnya sebagai Landasan, Orientasi, dan Rambu-rambu bagi Kehidupan Berbangsa dan Bernegara di Masa Lalu, kini, dan Masa Mendatang”, [Addressing Pancasila and Its Effectiveness as Platforms Orientations, and Signs for Nations in the Past, Present, and Future], delivered at symposium and Sarasehan Hari Lahir Pancasila, which took place at Gadjah Mada University on $14^{\text {th }}$ and $15^{\text {th }}$ August $2006: 20-21$. 
Sweet, Alec Stone. "The Politics of Constitutional Review in France and Europe." International Journal of Constitutional Law 5, no. 1 (2007): 69-92.

Treanor, William Michael. "Judicial Review Before Marbury", Stanford Law Review 58, no. 2 (2005): 455-562.

Uzman J., T. Barkhuysen and M.L. van Emmerik. "The Dutch Supreme Court: A Reluctant Positive Legislator?” Electronic Journal of Comparative Law 14, no.3 (2010): 1-35

Wantu, Fence M. "Mewujudkan Kepastian Hukum, Keadilan, dan Kemanfaatan Dalam Putusan Hakim di Peradilan Perdata Perdata [Realising Legal Certainty, Justice and Beneifts of Justice's Decosopm in Civil Courts]." Jurnal Dinamika Hukum 12, no. 3 (2012): 479-489, https://doi.org/10.20884/1. jdh.2012.12.3.121

Winataputra, Udin Saripudin. "Implementasi Kebijakan Nasional Pembangunan Karakter Bangsa Melalui Pendidikan Karakter (Konsep, Kebijakan, dan Kerangka Programatik) [The Implementation of National Policy on the Development of the Character of the Nation through Character Education (Concept, Policy, and Pragmatic Framework)].” Paper., 2013.

Yudhista, Dhea. "Arah Pembangunan Hukum Nasional Menurut UUD NRI 1945 [The Development of National Law based on the 1945 Constitution]." February 29, 2016. https://fh.umj.ac.id/arahpembangunan-hukum-nasionalmenurut-undang-undang-dasar-negara-republik-indonesia-tahun-1945/. 